\title{
IDENTIFIKASI DAN PERHITUNGAN TOTAL BAKTERI PADA KARANG PORITES SP DI GOSONG BOKOR DAN PULAU PANJANG, KABUPATEN JEPARA, JAWA TENGAH
}

Identification and Calculation of Total Bacteria in Porites sp at Gosong Bokor and Panjang Island Jepara Regency, Central Java

\section{Siti Fatma Assyifa, Pujiono Wahyu Purnomo*), Oktavianto Eko Jati}

Program Studi Manajemen Sumberdaya Perairan, Departemen Sumberdaya Akuatik

Fakultas Perikanan dan Ilmu Kelautan Universitas Diponegoro

Jl. Prof. Soedarto, SH, Tembalang, Semarang, Jawa Tengah - 50275, Telp/Fax. +6224 7474698

Email :sitifatmaassyifa@gmail.com

\begin{abstract}
ABSTRAK
Pulau Panjang merupakan salah satu pulau yang berada di Kelurahan Ujung Batu, Kecamatan Jepara, Kabupaten Jepara, Jawa Tengah. Wilayah Besarnya potensi bawah laut yang ada di Pulau Panjang menjadikan Pulau Panjang sebagai kawasan wisata. Gosong Bokor merupakan lokasi penelitian dimana gosong bokor terbentuk dari komponen pasir dan juga kerikil. Porites sp merupakan salah satu jenis karang yang mampu bertahan hidup dalam kondisi lingkungan yang ekstrim seperti tumbuh pada lingkungan berpasir. Tujuan dari penelitian ini adalah untuk mengetahui jenis bakteri yang terdapat pada karang Porites sp di Pulau Panjang dan Gosong Bokor dan total bakteri pada masing - masing lokasi sampling. Penelitian ini dilaksanakan pada bulan Maret 2018. Metode yang digunakan pada penelitian ini adalah metode deskriptif. Pengambilan sampel dilakukan pada 2 lokasi berbeda dengan 4 titik sampling. Jenis bakteri yang diperoleh dari penelitian ini adalah Vibrio cincinnatiensis, Vibrio alginolyticus, Brevibacteriun fulvum, Bacillus subtilis, Lactobacillus casei, Bacillus badius, Corynebacterium kutscheri, Bacillus sphaericus, Bacillus insolitus. Total bakteri yang diperoleh pada lokasi sampling di Gosong Bokor pada titik sampling I yaitu sebesar 9,6 x10 $\mathrm{Cfu} / \mathrm{ml} \mathrm{dan} \mathrm{pada} \mathrm{titik}$ sampling II yaitu sebesar 4,2 × $10^{5} \mathrm{Cfu} / \mathrm{ml}$, hasil yang diperoleh dilokasi sampling di Pulau Panjang dimana pada titik sampling III yaitu sebesar $2,8 \times 10^{2} \mathrm{Cfu} / \mathrm{ml}$ dan pada titik sampling IV yaitu sebesar $6,5 \times 10^{4} \mathrm{Cfu} / \mathrm{ml}$
\end{abstract}

Kata kunci: Bakteri, Karang Porites sp, Gosong Bokor,Pulau Panjang.

\section{ABSTRACT}

Pulau Panjang is one of the islands in Ujung Batu Village, Jepara District, Jepara Regency, Central Java. The potential underwater in Pulau Panjang used as a tourist destination. Gosong Bokor is a research location where Gosong Bokor are formed from sand and gravel components. Porites sp is a type of coral that can survive in extreme environmental conditions such as growing in sandy environments. The purpose of this study was to determine the types of bacteria present in the Porites sp coral in Panjang Island and Gosong Bokor and the total bacteria at each sampling location. This research was carried out in March 2018. The method used in this research is descriptive method. Sampling was done in 2 different locations with 4 sampling points. The types of bacteria obtained from this study were Vibrio cincinnatiensis, Vibrio alginolyticus, Brevibacteriun fulvum, Bacillus subtilis, Lactobacillus casei, Bacillus badius, Corynebacterium kutscheri, Bacillus sphaericus, Bacillus insolitus. The total bacteria obtained at the sampling location at Gosong Bokor at sampling point 1 is $9,6 \times 10^{5} \mathrm{Cfu} / \mathrm{ml}$ and at the sampling point $\mathrm{II}$ is $4,2 \times 10^{5} \mathrm{Cfu} / \mathrm{ml}$, the results obtained at the sampling location on Pulau Panjang where at sampling point III is $2,8 \times 10^{2} \mathrm{Cfu} / \mathrm{ml}$ and at the sampling point IV is $6,5 \times 10^{4} \mathrm{Cfu} / \mathrm{ml}$

Keywords: Bacteria, Porites sp, Gosong Bokor, Panjang island

*)Penulis Penanggungjawab 


\section{PENDAHULUAN}

Pulau Panjang merupakan salah satu pulau yang berada di Kelurahan Ujung Batu, Kecamatan Jepara, Kabupaten Jepara, Jawa Tengah. Pulau Panjang sebagai salah satu kawasan kepulauan yang memiliki luas daratan kurang lebih tujuh hektar. Wilayah Pulau Panjang memiliki potensi bawah laut yang berbeda - beda. Besarnya potensi bawah laut yang ada di Pulau Panjang menjadikan Pulau Panjang sebagai kawasan wisata.

Gosong adalah bentukan daratan yang terkurung pada suatu perairan. Komponen yang membentuk gosong dapat terdiri dari pasir, dan kerikil. Gosong dapat terlihat apabila tidak terjadi pasang, namun gosong dapat hilang atau tidak terlihat lagi apabila pasang pada suatu kawasan perairan terjadi secara rutin. Kedalaman pada gosong sendiri tidak terlalu dalam, hal ini yang menyebabkan terdapat karang yang mampu hidup pada kawasan gosong tersebut. Bentuk gosong sangat dipengaruhi oleh arus (Usman dan Dida, 2009). Demikian halnya dengan gosong Bokor yang berada di Laut Jawa, gosong Bokor yang ada pada Laut Jawa terdapat banyak terumbu karang yang hidup di kawasan tersebut.

Pertumbuhan karang dipengaruhi oleh berbagai faktor diantara suhu dan cahaya. Pada umumnya karang tidak dapat berkembang dengan baik apabila kondisi perairan keruh. Hal ini dikarenakan terhambatnya proses fotosintesis yang dilakukan oleh zooxanthellae sehingga hasil dari fotosisntesis tersebut tidak dapat menjadi asupan bagi karang untuk dapat tumbuh dengan baik. Tidak hanya kekeruhan pada air yang mempengaruhi pertumbuhan pada karang. Tingkat kedalaman perairan pun akan mempengaruhi laju pertumbuhan dari karang tersebut. Hal ini diperkuat oleh Prasetia (2002) bahwa kemampuan pada zooxanthellae dalam melakukan fotosintesis akan berkurang apabila cahaya yang masuk kedalam badan perairan berkurang. Tujuan penelitian ini adalah untuk mengetahui jenis bakteri dan kelimpahan bakteri yang ada pada jenis karang Porites sp di Pulau Panjang dan Gosong Bokor, Kabupaten Jepara.

\section{MATERI DAN METODE PENELITIAN}

Materi yang digunakan dalam penelitian ini adalah air sampel yang berasal dari sampel karang yang ada di Gosong Bokor dan Pulau Panjang, Jepara. Alat yang digunakan dalam penelitian adalah Global Positioning System (GPS), mortar, alu, botol Winkler, kamera underwater, cawan petri, bunsen, tabung kultur dan alat tulis.

Metode yang digunakan dalam penelitian ini adalah metode deskriptif. Metode ini digunakan dengan bertujuan untuk memberikan gambaran dan deskripsi pada suatu objek dengan cara deskripsi. Hal ini diperkuat oleh Danim (2003) yang menjelaskan bahwa metode penelitian deskriptif bertujuan untuk menjelaskan kondisi suatu objek tertentu secara deskriptif dan bersifat faktual. Lokasi penelitian terdiri atas dua lokasi yang berbeda. Lokasi pertama adalah Gosong Bokor dimana terdapat dua titik lokasi sampling dan lokasi kedua adalah Pulau Panjang yang terdapat dua lokasi titik sampling.

Data primer yang diperoleh secara langsung di lapangan terdiri dari pengukuran arus, kedalaman, kecerahanan, salinitas, $\mathrm{pH}$, sedangkan data sekunder berupa data hasil identifikasi bakteri dan total kelimpahan bakteri yang diperoleh dari Laboratorium Balai Besar Perikanan Budidaya Air Payau.

\section{Identifikasi Bakteri}

Identifikasi bakteri dilakukan dengan cara melakukan sterilisasi pada alat - alat yang akan digunakan. lalu dilakukan proses kultur bakteri dengan menggunakan metode teknik goresan. Setelah dilakukan proses kultur bakteri, tahap selanjutnya adalah pemurnian bakteri yang telah di peroleh dari hasil kultur. Uji presumtif dilakukan setelah pemurnian bakteri selesai, uji presumtif dilakukan untuk mengetahui sifat, morfologi, dan jenis bakteri. Uji presumtif terdiri dari uji katalase, oksidase, gram, dan biokimia. Uji yang dilakukan selanjutnya adalah uji biokimia, dimana uji biokimia ini dilakukan untuk mengetahui reaksi yang ditimbulkan oleh isolate setelah dilakukan pemurnian atau kultur selama 48 jam. Uji biokimia meliputi uji oksidatifffermentativ, uji Sulphide Indole Motility (SIM), uji glucose (acid), uji sulfida $\left(\mathrm{H}_{2} \mathrm{~S}\right)$, uji gula - gula, uji pewarnaan spora. Proses pengamatan jenis bakteri dilakukan dengan menggunakan mikroskop binokuler. Proses Identifikasi dilakukan dengan menggunakan Cowan and Steel's Manual for The Identification of Medical Bacteria. Third Edition (2003), Bergey's Manual of Determinative Bacteriology (1975) dan SNI 7545.1:2009. Metode Identifikasi Bakteri pada Ikan secara Konvensional bagian I: Edwardsiella ictaluri.

\section{Perhitungan Total Bakteri}

Perhitungan total bakteri menggunakan metode SNI 7545.1;2009 dimana perhitungan dilakukan dengan cara dihitung secara manual dengan menggunakan colony counter, jumlah koloni yang dihitung menggunakan rumus TPC (Total Plate Count) dengan rumus :

Keterangan :

$$
\mathrm{N}(\mathrm{Cfu} / \mathrm{ml} / \mathrm{ml})=\mathrm{n}(\mathrm{Cfu} / \mathrm{ml}) / 0,1(\mathrm{ml}) \times 10^{\mathrm{x}}
$$

$\mathrm{n}=$ adalah jumlah koloni bakteri dalam plate agar

$10^{\mathrm{x}}=$ seri pengenceran 


\section{Pengukuran Parameter Lingkungan}

Pengamatan kualitas air yang dilakukan pada penelitian ini adalah kecerahan, kedalaman, temperatur air, salinitas, oksigen terlarut, kecepatan arus, $\mathrm{pH}$. Pengukuran kedalaman dan kecerahan menggunakan tongkat kedalaman dan secchi disk yang sudah dimodifikasi dengan rumus :

$$
D=\frac{k 1+k 2}{2}
$$

Dimana :

$\mathrm{D}=$ Kedalaman $(\mathrm{cm})$

$\mathrm{K} 1$ = posisi lempeng secchi disk dalam keadaan gelap $(\mathrm{cm})$

$\mathrm{K} 2$ = posisi lempeng secchi disk dalam keadaan remang - remang $(\mathrm{cm})$

Sedangkan pengukuran oksigen terlarut menggunakan metode winkler dimana pengukuran ini menggunakan botol BOD dititrasi menggunakan $\mathrm{Na}_{2} \mathrm{~S}_{2} \mathrm{O}_{3}$. Rumus yang digunakan untuk menghitung kadar oksigen terlarut adalah :

$$
\text { Oksigen terlarut }(\mathrm{mg} / \mathrm{l})=\frac{\mathrm{V} \times \mathrm{N} \times 8000}{50}
$$

Keterangan :

$\mathrm{V}=$ Volume titrasi $\mathrm{Na}_{2} \mathrm{~S}_{2} \mathrm{O}_{3}(\mathrm{ml})$

$\mathrm{N}=$ Normalitas $\mathrm{Na}_{2} \mathrm{~S}_{2} \mathrm{O}_{3}(0,025 \mathrm{~N})$

\section{HASIL DAN PEMBAHASAN}

Gosong Bokor merupakan salah satu gosong pasir yang terdapat di Laut Jawa, dimana lokasi sampling dilakukan pada titik koordinat $110^{\circ} 36^{\prime} 11,23^{\prime}$ ' LS dan $06^{\circ} 37^{\prime} 54,48^{\prime}$ " BT sebagai lokasi sampling pertama dan lokasi sampling kedua berada pada koordinat $110^{\circ} 36^{\prime} 12,61^{\prime \prime}$ LS dan $06^{\circ} 37^{\prime} 47,36^{\prime \prime}$ BT. Lokasi Gosong Bokor memiliki jarak tempuh 4,07 mil dari Pulau Panjang dan pada bagian timur Gosong Bokor adalah laut Jawa Pulau Panjang sendiri berada pada daerah timur laut Gosong Bokor.

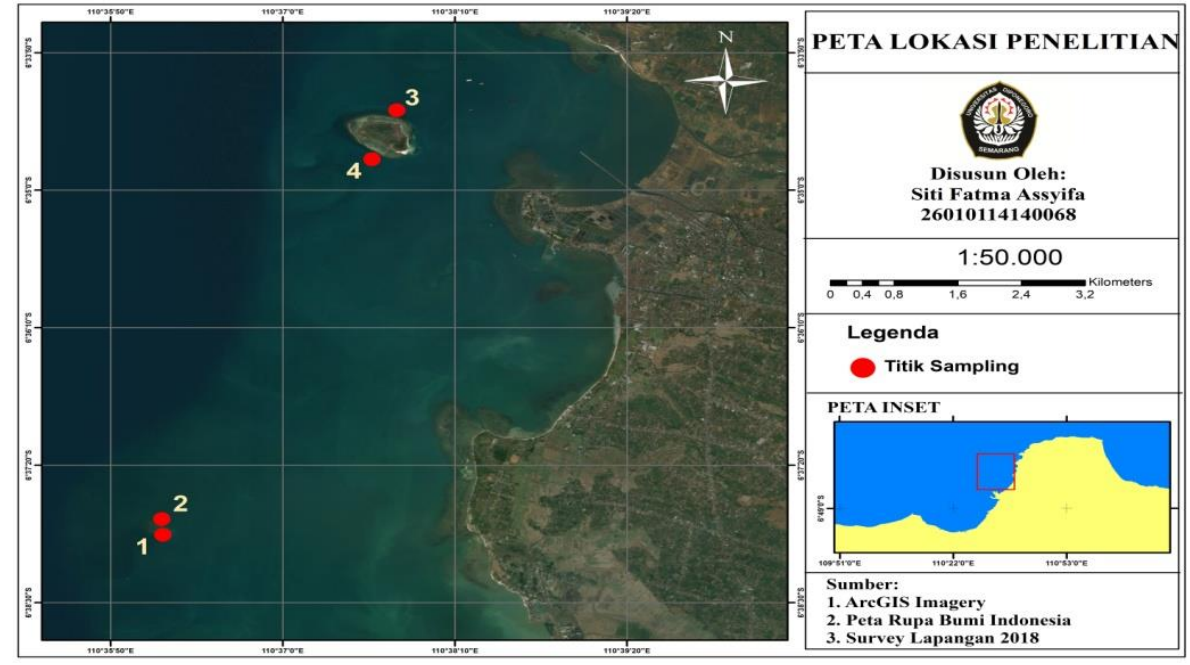

Gambar 1. Peta Lokasi Penelitian

\section{Parameter Lingkungan}

Hasil pengukuran nilai parameter lingkungan di lokasi sampling tersaji pada tabel 1 sebagai berikut:

Tabel 1. Nilai Parameter Lingkungan di Lokasi Sampling

\begin{tabular}{lllllll}
\hline Parameter & \multicolumn{3}{c}{ Gosong Bokor } & \multicolumn{3}{c}{ Pulau Panjang } \\
\cline { 2 - 7 } Lingkungan & Titik I & Titik II & Kisaran & Titik III & Titik IV & Kisaran \\
\hline Kedalaman(cm) & 198 & 187 & 192,5 & 297 & 314 & 305,5 \\
Kecerahan (\%) & 100 & 100 & 100 & 100 & 100 & 100 \\
Arus (m/det) & 0,25 & 0,20 & 0,025 & 0,08 & 0,07 & 0,075 \\
Salinitas $(\%)$ & 31 & 31 & 31 & 30 & 30 & 30 \\
pH & 8 & 8 & 8 & 7 & 7 & 7 \\
Suhu $\left({ }^{\circ} \mathrm{C}\right)$ & 29 & 29 & 29 & 30 & 30 & 30 \\
DO $(\mathrm{mg} / \mathrm{l})$ & 4,8 & 5,2 & 5 & 6 & 6,4 & 6,2 \\
\hline
\end{tabular}




\section{Hasil Identifikasi Bakteri}

Hasil pengamatan bakteri pada jenis karang Porites sp pada Gosong Bokor dan Pulau Panjang, Jepara adalah sebagai berikut:

Tabel 2. Hasil Identifikasi Bakteri

\begin{tabular}{|c|c|c|c|c|}
\hline \multirow[t]{2}{*}{ No. } & \multicolumn{2}{|c|}{ Gosong Bokor } & \multicolumn{2}{|c|}{ Pulau Panjang } \\
\hline & Titik I & Titik II & Titik III & Titik IV \\
\hline 1. & $\begin{array}{l}\text { Vibrio } \\
\text { cincinnatiensis }\end{array}$ & $\begin{array}{l}\text { Brevibacterium } \\
\text { fulvum }\end{array}$ & Lactobacillus casei & Bacillus sphaericus \\
\hline 2. & $\begin{array}{l}\text { Vibrio } \\
\text { alginolyticus }\end{array}$ & Bacillus subtilis & $\begin{array}{l}\text { Corynebacterium } \\
\text { kutscheri }\end{array}$ & Bacillus insolitus \\
\hline 3. & & & & Bacillus badius \\
\hline
\end{tabular}

2 bakteri gram negatif yang ditemukan pada penelitian ini adalah Vibrio cincinnatiensis dan Vibrio alginolyticus yang merupakan bakteri anaerobik fakultatif dimana bakteri ini mampu hidup baik dengan oksigen ataupun tidak dengan oksigen.

Bakteri mampu membantu mengurangi terjadinya kerusakan pada karang akibat pencemaran bahan organik. Menurut Radjasa dan Agus (2005), yang menyatakan bahwa bakteri memiliki potensi dalam memecahkan masalah pencemaran dalam lingkungan perairan dengan memanfaatkan bagian biofilm pada karang tersebut. Hasil penelitian 4 isolat karang Porites sp yang diperoleh dari 2 lokasi sampling yang berbeda yaitu Pulau Panjang dan Gosong Bokor terdapat sembilan spesies bakteri yang berada di karang Porites sp. Hasil ini diperoleh setelah dilakukan uji presumtif, uji biokimia dan identifikasi. Sembilan jenis bakteri yang ditemukan 5 diantaranya ditemukan pada Pulau Panjang dan 4 pada Gosong Bokor. Adapun 5 spesies yang teridentifikasi pada Pulau Panjang yaitu Corynebacterium kutscheri, Lactobacillus casei, Bacillus badius, Bacillus sphaericus, Bacillus insolitus dari hasil identifikasi, genus Bacillus sp yang paling banyak ditemukan pada Pulau Panjang. 4 spesies lainnya yang ditemukan pada Gosong Bokor adalah Vibrio cincinnatiensis, Vibrio alginolyticus, Brevibacterium fulvum, Bacillus subtilis.

Corynebacterium kutscheri ditemukan pada isolat karang yang berasal dari lokasi sampling Pulau Panjang pada titik sampling 1. Berdasarkan hasil uji presumtif bakteri Corynebacterium kutscheri merupakan bakteri Gram positif, dengan hasil uji oksidase dan katalase memberikan nilai positif. Corynebacterium kutscheri merupakan jenis bakteri anaerob fakultatif, bakteri ini ditemukan pada rangka karang Porites sp. Pada saat pengamatan makroskopis ciri - ciri yang dapat dilihat pada bakteri Corynebacterium kutscheri adalah isolat membentuk titik - titik yang menyebar berwarna putih susu dan permukaan halus.

Bacillus sp ditemukan pada isolat karang yang berasal dari lokasi sampling Pulau Panjang dan gosong Bokor. Genus Bacillus sp didapatkan sebanyak empat spesies dengan spesies terbanyak ditemukan pada lokasi sampling di Pulau Panjang yaitu sejumlah 3 spesies. Berdasarkan hasil uji presumtif bakteri Bacillus sp merupakan bakteri gram positif dan merupakan bakteri jenis aerobic. Pada saat pengamatan makroskopis cirri yang dapat dilihat dari bakteri Bacillus sp ini adalah isolat yang berukuran besar dengan membentuk titik - titik berwarna putih dan menyebar.

Vibrio cincinnatiensis dan Vibrio alginolyticus berdasarkan hasil uji presumtif, bakteri Vibrio cincinnatiensis dan Vibrio alginolyticus merupakan jenis bakteri anaerobik fakultatif dimana bakteri ini menghasilkan katalase dan merupakan jenis bakteri gram negatif. Menurut Abubakar et al. (2011) yang menyatakan bahwa bakteri Vibrio sp merupakan bakteri patogen sehingga dapat menimbulkan penyakit, salah satu penyakit yang ditimbulkan dari bakteri Vibrio sp adalah luminous vibriosis yang berasal dari bakteri Vibrio harveyi penyakit ini menyebabkan penyakit serius pada budidaya udang dilaut.

Lactobacillus casei merupakan salah satu jenis bakteri yang ditemukan pada lokasi penelitian dimana bakteri ini merupakan bakteri gram positif dan bersifat anaerob fakultatif, bakteri ini . Lactobacillus casei bakteri ini ditemukan pada karang Porites sp pada lokasi penelitian di Pulau Panjang.

Brevibacterium fulvum merupakan salah satu jenis bakteri gram positif dan merupakan bakteri aerob obligat. Bakteri ini menghasilkan katalase dan oksidase pada saat dilaksanakan uji biokimia. Bakteri ini mampu menguraikan senyawa kimia

\section{Perhitungan Total Bakteri}

Hasil perhitungan total bakteri pada jenis karang Porites sp pada Gosong Bokor dan Pulau Panjang, Jepara adalah sebagai berikut:

Tabel 3. Hasil Perhitungan Total Bakteri

\begin{tabular}{cccc}
\hline \multicolumn{2}{c}{ Gosong Bokor } & \multicolumn{2}{c}{ Pulau Panjang } \\
\hline I & II & I & II \\
\hline $9,6 \times 10^{5} \mathrm{Cfu} / \mathrm{ml} / \mathrm{ml}$ & $4,2 \times 10^{5} \mathrm{Cfu} / \mathrm{ml}$ & $2,8 \times 10^{2} \mathrm{Cfu} / \mathrm{ml}$ & $6,5 \times 10^{4} \mathrm{Cfu} / \mathrm{ml}$ \\
\hline
\end{tabular}

Perhitungan total bakteri pada karang dilakukan untuk mengetahui jumlah koloni bakteri yang tumbuh pada media kultur baik bakteri yang bersifat menguntungkan maupun merugikan. Dari hasil perhitungan total bakteri pada 
lokasi penelitian diperoleh nilai total bakteri tertinggi terdapat di Gosong Bokor pada titik sampling I dengan nilai 9,6 $\mathrm{x} 10^{5} \mathrm{Cfu} / \mathrm{ml}$ dan nilai total bakteri terendah di Pulau Panjang terdapat pada titik sampling II dengan nilai $2,8 \mathrm{x} 10^{2} \mathrm{Cfu} / \mathrm{ml}$. Menurut Sumarsiha et al. (2010) yang menyatakan bahwa perhitungan total bakteri dilakukan dengan menghitung jumlah bakteri hidup keseluruhan yang berada pada media kultur dimana cara menghitungnya adalah dengan menghitung seluruh jumlah jenis bakteri yang tumbuh pada media kultur tersebut.

Menurut Saputri et al. (2016) yang menyatakan bahwa pada perairan dasar biasanya bakteri yang teridentifikasi merupakan bakteri yang bersifat fakultatif, dimana bakteri ini merupakan bakteri yang mampu membantu karang dalam merubah bahan organik sehingga dapat membantu karang dalam menyediakan nutrisi bagi zooxanthallae.

\section{Peran Bakteri Terhadap Karang Porites sp}

Keberadaan bakteri yang berasosiasi dengan karang Porites sp tentu akan mempengaruhi kondisi karang. Peran bakteri bagi karang Porites sp adalah mampu dalam mendegradasi bahan organik menjadi anorganik seperti fosfat, nitrat, karbondioksida. Keberadaan bakteri pada tubuh karang memiliki pengaruh yang signifikan, apabila terdapat bakteri pathogen pada tubuh karang yang tentunya berpengaruh pada kesehatan dan penyakit karang (Ampou et al., 2015). Kesehatan karang Porites sp merupakan hal yang harus diperhatikan, hal ini dikarenakan karang merupakan organisme yang sangat mempengaruhi ekosistem perairan laut.

Peran bakteri bagi karang Porites sp berbagai macam, hal ini dikarenakan jumlah bakteri yang ditemukan pada karang Porites sp bermacam - macam sehingga peranannya pun akan berbeda. Keberadaan bakteri pada karang Porites sp tentunya ada yang menjadi antibakteri bagi penyakit karang. Penyakit - penyakit karang seperti Black band diseases, Dark spot disease, Red band disease, White band disease, namun penyakit yang menyerang karang tidak hanya karena mikroorganisme berbagai faktor dapat menyebabkan karang Porites sp ini dapat terjangkit penyakit (Siringoringo, 2007).

\section{KESIMPULAN}

Jenis bakteri yang ditemukan pada karang Porites sp. di kawasan terumbu karang di Gosong Bokor, Jepara adalah Vibrio cincinnatiensis, Vibrio alginolyticus, Brevibacteriun fulvum, Bacillus subtilis. Pada Pulau Panjang, Jepara jenis bakteri yang ditemukan adalah Corynebacterium kutscheri, Lactobacillus casei, Bacillus badius, Bacillus sphaericus, Bacillus insolitus. Total bakteri yang terdapat di Pulau Bokor pada titik sampling I yaitu 9,6 x $10^{5} \mathrm{Cfu} / \mathrm{ml} \mathrm{dan} \mathrm{pada} \mathrm{titik}$ sampling II yaitu 4,2 x $10^{5} \mathrm{Cfu} / \mathrm{ml}$. Pada Pulau Panjang total bakteri yang diperoleh pada titik sampling III yaitu $2,8 \times 10^{2}$ $\mathrm{Cfu} / \mathrm{ml}$ dan pada titik sampling IV yaitu $6,5 \times 10^{4} \mathrm{Cfu} / \mathrm{ml}$.

\section{UCAPAN TERIMA KASIH}

Penulis mengucapkan terima kasih atas masukan dan saran yang telah diberikan oleh Prof. Dr. Ir. Supriharyono, MS, Sigit Febrianto, S.Kel., M.Si

\section{DAFTAR PUSTAKA}

Abubakar, H., A.T. Wahyudi dan M. Yuhana. 2011. Skrining Bakteri yang Berasosiasi dengan Spons Jaspis sp. Sebagai Penghasil Senyawa Antimikroba. Jurnal Ilmu Kelautan, 16(1): 35 - 40.

Ampou, EE., I Triyulianti dan S C Nugroho. 2015. Analisa Bakteri Pada Karang Scleractinia Berkaitan Dengan Fenomena La-Nina Di Kawasan Taman Nasional Bunaken. Jurnal Echotrophic, 7(2) : 126 - 130.

Cowan and Steel's Manual for The Identification of Medical Bacteria. Third Edition.

Danim, S. 2003. Riset Keperawatan Sejarah dan Metodologi. Penerbit Buku Kedoktern EGC : Jakarta. Hlm 25.

Prasetia, I N D. 2012. Rekrutmen Karang Di Kawasan Wisata Lovina. Jurnal Sains dan Teknologi, 1(2).

Purawisastra, S dan H. Yuniati. 2004. Penurunan Kadar Sianida Singkong Pahit Pada Proses Fermentasi Cair Bakteri Brevibacterium Lactofermentum BL - $1 \mathrm{M} 76$

Rajasa, O. K. dan A. Sabdono. 2005. Studi Kinetika Biodegradasi Senyawa Herbisida S-Triazine oleh Bakteri Karang. Pusat Studi Pesisir dan Laut Tropis Universitas Diponegoro. $14 \mathrm{hlm}$

Saputri, RA., N Widyorini dan PW Purnomo. 2016. Identifikasi Dan Kelimpahan Bakteri Pada Jenis Karang Acropora Sp. Di Reef Flat Terumbu Karang Pulau Panjang Jepara. Saintek Perikanan, 12(1) : 35 - 39.

Siringiro, R. M. 2007. Pemutihan Karang dan Beberapa Penyakit Karang. Jurnal Oseana, 32(4) : 29 - 37.

SNI 7545.1:2009. Metode Identifikasi Bakteri pada Ikan secara Konvensional- bagian 1: Edwardsiella ictaluri, Badan Standarisasi Nasional, $10 \mathrm{hlm}$.

Sumarsiha, S., B Sulistiyanton dan CS Utama. 2010. Pengaruh Aras Starter Lactobacillus sp Terhadap Performa Mikrobiologi Silase Ikan Dilihat Dari Total Bakteri, Bakteri Asam Laktat Dan Fungi. Jurnal Kesehatan, 3(1).

Usman, E dan D Kusnida. 2009. Karakteristik Dan Proses Pengendapan Sedimen Dasar Laut Di Perairan Gosong Bunga, Kualanamu Kab. Serdang Bedagei, Prov. Sumatera Utara Oleh. Jurnal Geologi Kelautan, 7(2). 